\title{
The Differences of Students' Self-Confidence Level in Full Day Class and Regular Class of Elementary School
}

\author{
Richma Hidayati ${ }^{1}$, Nur Hidayah ${ }^{2}$ \\ ${ }^{1}$ Faculty of Teacher and Educational Sciences, Guidance and Counseling, Muria Kudus University, Indonesia \\ ${ }^{2}$ Faculty of Educational Sciences, Guidance and Counseling, Malang State University, Malang, Indonesia \\ e-mail : richma.hidayati.1901119@students.um.ac.id ${ }^{1}$, nur.hidayah.fip@um.ac.id²
}

\begin{abstract}
This study aims to compare the students' self-confidence between special classes (full day class) and regular classes. The method used is a quantitative study with a comparative study as a research design. The research subjects were 90 students, 30 students form special class and 60 students from regular class. The results of this study have provided an overview of the differences between special classes and regular classes affecting the level of student confidence where students in special classes have high self-confidence compared to students in regular classes. And it can be concluded that self-confidence is formed and develops through the learning process in one's interactions with the environment so that class differences make different levels of student confidence.
\end{abstract}

Keywords: self-confidence. full day class, regular class

\section{Introduction}

Self-confidence is very influential on how people compare themselves with others (Kappes et al., 2019; Federičová et al., 2018). Self-confidence can be triggered by a number of different mechanisms, such as a natural increase in competition in the classroom, departure of classmates / friends from class, teacher policies that are more demanding due to higher school entrance exams (especially in classrooms where there are more students are preparing for the exam), and other factors. Gurler's research results also state that there are two categories of self-confidence, the first is extrinsic confidence where external factors greatly influence the level of student self-confidence and the second is extrinsic selfconfidence where self-assessment greatly affects the level of student self-confidence (Gürler, 2015).

During this time, they also began to judge themselves by comparing them with others. Children will easy to find and use social comparisons, especially for social norms and the appropriateness of certain types of behavior. As children grow older, they tend to use social comparison to evaluate and assess their own abilities. As a result of changes in their physical and cognitive structures, children in large classes in primary school try to appear more mature. They want to be treated as adults. There are significant changes in their social and emotional lives. In the large classes of primary school both boys and girls perceive that participation in groups creates a feeling that they are valuable. Not being accepted into a group can lead to serious emotional problems. Their friends are more important than ever. The need to be accepted by peers is very high. And this has a huge influence on their selfconfidence when they are at school.

Self-confidence has a characteristic key to starting something, especially to talk. Selfconfidence is a very important key in children's language development (Gürler, 2015). With complete self-confidence, children will not hesitate to say words and talk to anyone and their language intelligence is greatly influenced by their self-confidence. Self-confidence is a feeling and belief in one's ability to be able to achieve success by basing on one's own efforts and developing a positive assessment for himself and his environment so that a person can appear with confidence and be able to face everything calmly.

However, sometimes high self-confidence causes increased student anxiety in facing tests (Lawal et al., 2017). This is due to the desire of students to get perfect results in doing the tests they face and the perfection of the results obtained will affect success in academics,

\footnotetext{
${ }^{*}$ Corresponding author.

Received 05 December 2019 2020; Accepted 08 September 2020; Available online 01 December 2020 (C) 2020 JPI. All Rights Reserved
} 
and in the end the high self-confidence of students also has an impact on the height of one's anxiety. Self-confidence plays a role in making a meaningful contribution to the process of one's life. Self-confidence is one of the main assets for success to live a life of optimism and the key to a successful and happy life.

Self-confidence is an attitude and feeling that is confident in one's own abilities so that individuals are not anxious about doing an action, can feel freedom in doing things they like and are able to be responsible for actions that are done, polite and warm when interacting with people others, respect and accept other people, have the urge to show skills and know the strengths and weaknesses of oneself. Self-confidence appears in the attitude that accepts yourself as it is (Hariko \& Ifdil, 2017). Self-acceptance is an attitude that reflects pleasure in relation to one's own reality. This attitude is a manifestation of satisfaction with the quality of one's real abilities. A person's positive reaction to his own appearance will lead to a sense of satisfaction which will affect his mental development (Pettersson, 2018).

Students' appearance in school is also influenced by which class the student is in. At MI NU Banat Kudus, it is divided into two classes, namely a special class (full day class) and a regular class. This class division has a very big effect on students' confidence. This division in class has occurred since the first grade, where students in a special class are screening 30 students with the highest scores and the rest enter the regular class. This class difference has a huge effect on students' self-confidence in the school.

Lack of self-confidence will show behaviors such as, not being able to do much, always hesitating in carrying out tasks, not daring to speak if they don't get support, closing themselves off, tending to avoid communication situations as much as possible, withdrawing from the environment, getting a little involved in activities or groups, being aggressive, being defensive and taking revenge for treatment deemed unfair. Self-confidence is a positive mental attitude for someone who positions or conditions himself to evaluate himself and his environment so that he feels comfortable to carry out activities in an effort to achieve planned goals. In addition, self-confidence is an attitude that allows individuals to have a positive and realistic view of themselves and their situation.

The confidence that someone has makes them able to control the life they live so that they are able to do the best of what they have planned and expected. With good selfconfidence, they are also able to solve problems and work that are their own responsibility so that, the more individuals lose self-confidence, the more difficult it will be to decide the best thing to do for them, and tend to lose motivation (Fitri et al., 2018) in doing many things, especially studying.

There are so many factors that affect the self-confidence of students, especially students in Elementary Schools and equivalent. However, research on the self-confidence of elementary school students divided into special classes and regular classes has never been discussed and will be described in the results of this study. So that the purpose of this study is to compare the differences in self-confidence of SD / MI students who are in special classes (Full day class) and Regular classes to be a more in-depth analysis of other factors that have a big influence on student self-confidence.

\section{Method}

The method used by researchers in revealing the level of self-confidence of 4 th grade student at MI NU Banat who are in the Regular class and special class. This study uses a quantitative approach with correlation analysis and multiple regression. The population of this study came from a special class of 30 students and 60 students came from the regular class. The research instrument used a student self-confidence scale developed by Laustser (Lauster self-confidence scale) which was adjusted to the level of development and age of the student which was then analyzed using multiple regression.

The self-confidence indicators used as the research scale consist of five. The indicators of self-confidence shown in Table 1. 
Table 1. Indicators of Self-Confidence

\begin{tabular}{|c|c|}
\hline Dimentions & Definition \\
\hline $\begin{array}{l}\text { Confidence in self- } \\
\text { efficacy }\end{array}$ & Having a positive attitude towards oneself \\
\hline Optimistic & $\begin{array}{l}\text { A positive attitude of someone who always has a good view of } \\
\text { everything }\end{array}$ \\
\hline Objective & $\begin{array}{l}\text { The attitude of someone who views everything with the truth it } \\
\text { should be }\end{array}$ \\
\hline Responsibility & $\begin{array}{l}\text { The willingness of someone to bear everything that has become the } \\
\text { consequence }\end{array}$ \\
\hline Rational and realistic & $\begin{array}{l}\text { Someone has the ability to analyze problems or events by using } \\
\text { sensible thoughts. }\end{array}$ \\
\hline
\end{tabular}

The Lauster self-confidence scale consists of 15 statements that measure a person's confidence based on predefined indicators. Measurements are made using a Likert scale using a score of 1-3, participants are asked to provide an assessment that best describes themselves. Each statement is given 3 answer choices, namely: Appropriate (S), Less Suitable (KS) and Not Suitable (TS). The range of values obtained is 15-45. Provided that a score of $0-15$ is in the Low category, a score of $16-30$ is in the Fair category, and a score of $31-45$ is in the high category.

The total number of students is 90 , with 30 students coming from special classes in class $V$ and 60 students from regular classes in the same class, given the same confidence scale and then analyzed using multiple regression analysis which uses more than one variable, namely special class and class regular.

\section{Result and Discussion}

\section{Results} Table 2.

The results of descriptive analysis of student self-confidence can be explained in

Table 2. Self Confidence

\begin{tabular}{ccccc}
\hline No & Category & Special Class & Regular Class & Interval \\
\hline 1 & High & 28 & 0 & $31-45$ \\
2 & Enough & 2 & 23 & $16-30$ \\
3 & Low & 0 & 37 & $0-15$ \\
\hline & TOTAL & $\mathbf{3 0}$ & $\mathbf{6 0}$ & \\
\hline
\end{tabular}

The self-confidence scale used consists of five indicators (1), confident in one's own abilities, (2) optimistic, (3) objective, (4) responsibility and (5) rational and realistic.

Table 3. Multiple regression processing results

\begin{tabular}{llllll}
\hline \multicolumn{5}{c}{ Coeffisients $^{\mathbf{a}}$} \\
\hline & \multicolumn{6}{l}{$\begin{array}{l}\text { Unstandardized } \\
\text { Coefficients }\end{array}$} & $\begin{array}{l}\text { Standardized } \\
\text { Coefficients }\end{array}$ & t & Sig. \\
\hline & B & Std. Error & Beta & \\
\hline $\begin{array}{l}\text { (Constant) } \\
\text { confident in one's own }\end{array}$ & .739 & .026 & & 27.076 & .000 \\
$\begin{array}{l}\text { abilities } \\
\text { optimistic }\end{array}$ & .110 & .011 & .185 & 9.035 & .000 \\
objektive & .329 & .015 & .480 & 21.027 & .000 \\
Responsibility & .089 & .012 & .171 & 7.955 & .000 \\
\hline
\end{tabular}




\begin{tabular}{llllll}
\hline \multicolumn{6}{c}{ Coeffisients $^{\mathbf{a}}$} \\
\hline Model & \multicolumn{6}{l}{$\begin{array}{l}\text { Unstandardized } \\
\text { Coefficients }\end{array}$} & $\begin{array}{l}\text { Standardized } \\
\text { Coefficients }\end{array}$ & t & Sig. \\
\hline & B & Std. Error & Beta & 10.489 & .000 \\
\hline $\begin{array}{l}\text { Rasional dan } \\
\text { Realististic }\end{array}$ & .127 & .013 & .220 & & \\
\hline
\end{tabular}

a. Dependent Variable: loo_KD

Based on the Table 3, it can be seen that students in special classes fall into the high self-confidence category while students in regular classes fall into the moderate and low self-confidence category. The results of the comparative study analysis showed that there were differences in the confidence of students in special classes and in regular classes. A total of 28 students in the special class are in the high self-confidence category and 2 students are in the sufficient self-confidence category. While 2 classes in grade 4 are regular, a total of 23 students are in the sufficient self-confidence category and 37 students are in the low category. The results of this study have provided an overview of the differences between special classes and regular classes that affect students' confidence levels.

\section{Discussion}

Self-confidence is very influential on how people compare themselves with others (Kappes et al., 2019; Federičová et al., 2018). Self-confidence can be triggered by a number of different mechanisms, such as a natural increase in competition in the classroom, departure of classmates / friends from class, teacher policies that are more demanding due to higher school entrance exams (especially in classrooms where there are more students are preparing for the exam), and other factors. Gurler's research results also state that there are two categories of self-confidence, the first is extrinsic confidence where external factors greatly influence the level of student self-confidence and the second is extrinsic selfconfidence where self-assessment greatly affects the level of student self-confidence (Gürler, 2015).

Self-confidence is an attitude and feeling that is confident in one's own abilities so that individuals are not anxious about doing an action, can feel freedom in doing things they like and are able to be responsible for actions that are done, polite and warm when interacting with people others, respect and accept other people, have the urge to show skills and know the strengths and weaknesses of oneself. Self-confidence appears in the attitude that accepts yourself as it is (Hariko \& Ifdil, 2017). Self-acceptance is an attitude that reflects pleasure in relation to one's own reality. This attitude is a manifestation of satisfaction with the quality of one's real abilities. A person's positive reaction to his own appearance will lead to a sense of satisfaction which will affect his mental development (Pettersson, 2018).

Self-confidence is a belief that a person has that he is capable of behaving as needed to obtain the expected results (Lestari et al., 2019). In line with the research, children's selfesteem was measured by six items from the Behavioral Academic Self Esteem Scale (BASE), which reflects self-confidence and results in younger children are easier to persuade than children who are older and this difference disappears when controlled for selfconfidence. Apart from age, there are many factors that influence student self-confidence (Vrij \& Bush, 2000).

Self-confidence is influenced by several factors, namely self-concept, self-esteem, experience and education. Self-confidence development can be learned by looking at various important factors in accelerating the growth and development of self-confidence. Some of these factors are: Appearance / Style, Style of speaking / Speaking (Cimermanová, 2018), Style of conduct / Body language, right man in the right place (Vanaja \& Geetha, 2017). The process of achieving achievement is influenced by activity factors, organisms and environmental factors (Kastrup et al., 2018). Activity factors, namely factors that encourage individuals to learn, this factor is a psychological factor. Self-confidence is an activity factor. Organismal factors, namely factors related to the function of individual sensory organs whose 
sensitivity determines the individual's response to learning. Environmental factors, namely factors that psychologically affect the overall process.

The school environment is a major factor in student confidence. Special class and regular class at MI NU Banat provide a different atmosphere and environment for students who are ultimately leads to differences in student confidence in each class. What is very striking is the difference in the Full Day Class and the regular class at each level. The full day class, with students who overall have high self-confidence, is characterized by: when in the class they are more active, they are not ashamed to ask questions when given the opportunity to ask questions, When asked to come forward and solve problems, they are scrambling to answer the question, when the thematic discussing mathematics there are two children who raise their fingers and ask to be explained again because they do not understand it and that means they understand their weaknesses, they are also able to express what is in them, this is proven by they can express their respective opinions when asked by the teacher who was teaching.

This condition is different from the regular class, and it becomes more and more striking when in the regular class there are children with prominent intelligence, students who cannot tend to be quiet immediately, in the class do not talk much, even with classmates who do not talk much to each other, When asked the teacher who teaches to come forward to work on the questions they are reluctant to come forward, Students also show low selfconfidence when confronted in groups, especially if there are children in the group who are smart, they prefer silence and cannot express opinions or what to think and this arises when sports theme subjects with group activities outside the room.

The results of hypothesis testing in this study indicate a significant difference between students' self-confidence in special classes and regular classes. This means that many factors affect student confidence, especially elementary school students. In line with research (Flowers \& Marston, 2017), explain gender differences to be one of the factors that cause differences in student self-confidence. Gender (the difference between men and women) can indeed be one of the factors that make students' self-confidence high and low, but in this study all students are female because it is a special school for girls and what distinguishes them is the difference in special classes and regular classes at each grade level, so the differences between special classes and regular classes are also one of the factors that cause differences in student confidence.

Gender disparities can affect student self-confidence resulting from factors of a competitive school environment (Federičová et al., 2018). In this study it is in line with the research results (Federičová et al., 2018), Seeing the differences that appear in special classes and regular classes which are the learning environment of students, when students in regular classes are combined in groups with special classes (full day class), their selfconfidence decreases and they will be more silent.

The academic environment and atmosphere have a huge influence on students' selfconfidence. The difference in treatment in special classes and regular classes in creating an academic atmosphere in the learning process is the cause of differences in students' selfconfidence levels. In line with Bolivar research and friends (Bolívar-Cruz et al., 2018) which explains that students' self-confidence, self-efficacy and assessment incentives in students have an impact on oral presentation competence in an academic setting. Therefore, in looking at gender differences, the treatment given in an academic atmosphere will be different. The results of Bolivar et al's research support this study, because the most striking difference between regular and special classes is the difference in class facilities so that it affects the academic atmosphere in the classroom which ultimately leads to differences in students' confidence levels.

Based on the results of hypothesis testing, it is known that students in special classes have a high level of self-confidence, while students in regular classes tend to have low selfconfidence. This is in accordance with the opinion. Self-confidence is an attitude or belief in one's own abilities, so that in his actions he is not too anxious. (Passiatore et al., 2019), feel free to do things as you wish (Komara, 2016) and responsibility for his actions (Ramadhani et al., 2014), polite in interacting with others (Wahyu Nanda Eka Saputra, 2018), have an 
achievement drive (Komara, 2016; Walid et al., 2015) and be able to recognize your own strengths and weaknesses (Hooper, 2018). The formation of self-confidence is a process of learning how to respond to various stimuli from outside themselves through interaction with their environment. The difference in interactions in special classes and regular classes also has a very big effect on students' self-confidence.

Self-confidence is not a trait that is inherited (innate) but is obtained from life experiences, and can be taught and instilled through education, so that certain efforts can be made to form and increase self-confidence. Thus self-confidence is formed and developed through the learning process in one's interactions with the environment. The differentiation of students into special classes and regular groups raises very crucial problems, especially in student self-confidence. So that there is a difference in the level of confidence of students in special classes and regular classes.

There is a significant difference in the confidence of students in special classes and regular classes at $\mathrm{MI} \mathrm{NU}$ Banat. Based on the analysis of comparative studies, this difference is caused by environmental factors formed in special classes and regular classes. In this study only compared the differences in student confidence in special classes and regular classes, but there are many factors that need to be studied further and have not been discussed in this study. This study only discusses differences in students' self-confidence levels which are influenced by factors of differences in the environment and academic atmosphere in special classes (full-day class) and regular class. Gender differences were not discussed because the school which was the research site was a special school for girls. So it needs to be reviewed and carried out further research on differences in student selfconfidence in terms of gender because there are special schools for boys, schools for girls, schools with mixed students, schools with ethnic differences, special religious schools and general schools.

\section{Conclusions}

There is a significant difference in the confidence of students in special classes and regular classes at $\mathrm{MI} \mathrm{NU}$ Banat. Based on the analysis of comparative studies, this difference is caused by environmental factors formed in special classes and regular classes. In this study only compared the differences in student confidence in special classes and regular classes, but there are many factors that need to be studied further and have not been discussed in this study. This study only discusses differences in students' self-confidence levels which are influenced by factors of differences in the environment and academic atmosphere in special classes (full-day class) and regular class. Gender differences were not discussed because the school which was the research site was a special school for girls. So, it needs to be reviewed and carried out further research on differences in student selfconfidence in terms of gender because there are special schools for boys, schools for girls, schools with mixed students, schools with ethnic differences, special religious schools and general schools.

\section{Acknowledgement}

This research has been funded by BPPDN (Beasiswa Pascasaraja Dalam Negeri) which provides full support for education and research during further studies of S3 Postgraduate Program, State University of Malang.

\section{Refference}

Bolívar-Cruz, A., Verano-Tacoronte, D., \& Galván-Sánchez, I. (2018). Do self-efficacy, incentives and confidence in public speaking influence how students self-assess? $\begin{array}{llll}\text { Cultura } y & \text { Educacion, 30(3), 528-555. }\end{array}$ https://doi.org/10.1080/11356405.2018.1488420

Cimermanová, I. (2018). The effect of learning styles on academic achievement in different forms of teaching. International Journal of Instruction, 11(3), 219-232. https://doi.org/10.12973/iji.2018.11316a

Federičová, M., Pertold, F., \& Smith, M. L. (2018). Children left behind: self-confidence of 
pupils in competitive environments. Education Economics, 26(2), 145-160. https://doi.org/10.1080/09645292.2017.1395811

Fitri, E., Zola, N., \& Ifdil, I. (2018). Profil Kepercayaan Diri Remaja serta Faktor-Faktor yang Mempengaruhi. JPPI (Jurnal Penelitian Pendidikan Indonesia), 4(1), 1. https://doi.org/10.29210/02017182

Flowers, J., \& Marston, A. (1972). Modification of low self-confidence in elementary school children. Journal of Educational Research, 66(1), 30-34. https://doi.org/10.1080/00220671.1972.10884394

Gürler, İ. (2015). Correlation between Self Confidence and Speaking Skill. Curr Res Soc Sci, 1(2), 14-19.

Hariko, R., \& Ifdil, I. (2017). Analisis Kritik Terhadap Model Kipas; Konseling Intensif Progresif Adaptif Struktur. Jurnal Konseling Dan Pendidikan, 5(2), 109. https://doi.org/10.29210/120500

Hooper, C. (2018). The Mahabharata. Psychological Perspectives, 61(1), 76-91. https://doi.org/10.1080/00332925.2018.1422931

Kappes, H. B., Fasolo, B., Han, W., Barnes, J., \& Ter Meer, J. (2019). Poor peer work does not boost student confidence. Journal of Behavioral Decision Making, January, 1-12. https://doi.org/10.1002/bdm.2148

Kastrup, H., Mallow, J. V, Lestari, H. P., Hartoto, S., Khory, F. D., \& Prakoso, B. B. (2018). The effectiveness of collaborative problem based physics learning ( CPBPL) model to improve student' $s$ self-confidence on physics learning The effectiveness of collaborative problem based physics learning ( CPBPL ) model to improve s tudent's self-con. IOP Conf. Series: Journal of Physics: Conf. Series 997 (2018) 012008. https://doi.org/doi :10.1088/1742-6596/997/1/012008

Komara, I. B. (2016). Hubungan antara Kepercayaan Diri dengan Prestasi Belajar dan Perencanaan Karir Siswa. Jurnal Psikopedagogia, 5(1), 33-42. journal.uad.ac.id

Lawal, A. M., Idemudia, E. S., \& Adewale, O. P. (2017). Academic self-confidence effects on test anxiety among nigerian university students. Journal of Psychology in Africa, 27(6), 507-510. https://doi.org/10.1080/14330237.2017.1375203

Lestari, T., Mulyana, E. H., Nurzaman, I., Gandana, G., \& Apriyaningsih, E. (2019). Exploring the integrating potentials of role playing with YouTube in building student's self confidence. Journal of Physics: Conference Series, 1318(1). https://doi.org/10.1088/1742-6596/1318/1/012014

Passiatore, Y., Pirchio, S., Oliva, C., Panno, A., \& Carrus, G. (2019). Self-efficacy and anxiety in learning English as a Foreign language: Singing in class helps speaking performance. Journal of Educational, Cultural and Psychological Studies, 2019(20), 121-138. https://doi.org/10.7358/ecps-2019-020-passi

Pettersson, C. (2018). Psychological well-being, improved self-confidence, and social capacity: bibliotherapy from a user perspective. Journal of Poetry Therapy, 31(2), 124-134. https://doi.org/10.1080/08893675.2018.1448955

Ramadhani, T. N., Putrianti, F. G., Psikologi, F., \& Tamansiswa, U. S. (2014). Hubungan antara kepercayaan diri dengan citra diri pada remaja akhir. Jurnal UST Jogja, 4(2), 22-32.

Vanaja, Y., \& Geetha, D. (2017). A Study on Locus of Control and Self Confidence of High School Students. International Journal of Research Granthaalayah, 5, 598-602. https://doi.org/10.5281/zenodo.841186

Vrij, A., \& Bush, N. (2000). Differences in suggestibility between 5-6 and 10-11 year olds: The relationship with self confidence. Psychology, Crime and Law, 6(2), 127-138. https://doi.org/10.1080/10683160008410837

Wahyu Nanda Eka Saputra, H. P. (2018). Meningkatkan Percaya Diri Siswa melalui Teknik Cognitive Defusion. Jurnal Kajian Bimbingan Dan Konseling, 3(1), 14-21. http://journal2.um.ac.id/index.php/jkbk

Walid, A., Gamal, R., Kusumah, T., Doktoral, P., \& Doktoral, P. (2015). Pengaruh Rasa Percaya Diri Terhadap Motivasi Berprestasi Siswa pada Mata Pelajaran IPA. Repository lain Bengkulu, 217-226. 